\title{
Analysis of Waiting Time for Patient Service Using Lean Concept in Outstanding Installations Stella Maris Hospital, Makassar City in 2022
}

\author{
Nur Miftahul Janna ${ }^{1}$, Hartati $\mathrm{S}^{2}$, Aprilia Elly ${ }^{1}$ \\ Corresponding Email: nurmiftahuljannah96@gmail.com \\ ${ }^{1}$ Hospital Administration Study Program, Faculty of Health Sciences, Cokroaminoto \\ University Makassar, Indonesia \\ ${ }^{2}$ Midwifery Study Program, Faculty of Health Sciences, University of Cokroaminoto \\ Makassar, Indonesia \\ Received: December 11, 2021
}

Received in Revised: January 17, 2022

Accepted: January 27, 2022

\begin{abstract}
There is a growing worry among hospitals throughout the globe about the impact of outpatient services, which account for a considerable portion of their total income and are predicted to overtake their inpatient counterparts. As more people seek medical attention in the future, this might lead to more money coming in to the hospitals. The goal of this study is to use the lean concept to assess patient service wait times at Stella Maris Hospital Makassar's outpatient department. Mixed methods were used in the research, which included measuring the wait time for patient services for up to 100 patients and and by following interview procedures with eight informants, including the head of the outpatient installation (1 person), the admission officer ( 3 individuals), the hospital director ( 1 individual), and nurses (3 people). The interviewees' responses were investigated via data reduction, data display, and conclusion drafting.. Data reduction, data visualization, and conclusion writing were used to examine the respondents' replies. A patient care process flowchart is constructed to evaluate the data's quality. it is not installed an rs sim, which resulted in long lines at the pick-up counter, doctors being late, and patients being unable to pick up their orders on time. It is also essential that hospital SIMRS be linked to each other throughout the whole facility, that repairs are made, and that the results are quantified and can be used for decision-making purposes.
\end{abstract}

Keywords: Outpatient, Lean Hospital

\section{Introduction}

SPM (Minimum Service Standards) contain quality indicators such as waiting time for patient treatment, which must satisfy a minimum set of 60 minutes as a minimum for outpatient facilities' patient services (Kepmenkes no.129 of 2008 About Hospital Minimum Service Standards, 1992). Healthcare facilities all across the globe are worried about how to best provide outpatient services to their patients. It is expected that in the near future, the revenue from outpatients will exceed that from inpatients, which will increase the hospital's finances since the number of outpatients is higher than the number of patients who are in the hospital. For further details, see Law No. 44 of 2009.

Outpatients' perceptions of the quality of health care services are an important barometer of that quality. A study published in 2003 by Ryan, G. et al. Some of the most common concerns that emerge in outpatient services at hospitals are long wait times, administrative processes and information availability. Patient satisfaction is influenced by outpatients' views about wait 
times for health-care procedures. This affects the quality of healthcare services (Maxwell RJ, 1984).

Multiple regression analysis revealed that patient satisfaction was influenced by the patient's perception of waiting time and the speed at which they received service, as reported in the 2016 study by Torry et al. with the title Factors Affecting Waiting Time for Health Services in Relation to Outpatient Patient Satisfaction in Internal Medicine Clinic Dr. Iskak Tulungagung (P 0.05). In the end, a shortage of doctors on duty is the most important contributor to longer service waits and worse customer satisfaction.

In a research titled Variables Affecting the Optimization of Outpatient Unit at Hospital X by Kurnia Widyaningrum et al. (2015), the following factors were found: Results showed that there was a mismatch between the usability of space and staff productivity. Even though the room's usefulness is just $22.4 \%$, the optimization of each doctor is near-perfect at $141.6 \%$, $172.9 \%$, and $68.75 \%$, respectively. A fishbone diagram demonstrates that a lack of personnel and a claustrophobic atmosphere are the most important factors leading to poor performance in the outpatient unit. An inefficient monitoring and evaluation (monev) system was the root cause of the problem, according to a 5 whys research. The monev team in this outpatient unit has been reinvigorated by providing them with monev training as a technique to increase optimization. As part of an MBA program in Lean Supply Chain Management in Vijayawada, India, a student worked with Help Hospital to put the ideas learned in class into reality. The program resulted in a reduction in outpatient waiting times of more than an hour to 15 minutes, which also increased staff productivity by 114 percent. Using this example, it can be shown that even those with little or no prior knowledge of lean ideas may accomplish impressive results when provided with the appropriate resources (Miller \& Chalapati, 2015).

When it comes to customer service, $90 \%$ of the time is spent on non-value-added tasks, according to Elisabeth (2017)'s research results. Using the lean technique in a simulative way (i.e. 5S, Kanban Inventory, visual management), the non-value-added activities fell to $78 \%$ of all activities, while only $21 \%$ of total activities were value-added activities.

One technique for reducing waste and non-value-added processes while increasing patient safety and happiness is to implement sustainable Lean hospital concepts and principles (Poksinska, 2010). Some countries, such as America, the UK and Australia, have proven success in using this strategy (Kinsman et al., 2017).

There was a 100-minute wait in 2017, a 120-minute wait in 2018, and a 99-minute wait in 2019 for outpatient care at Makassar's Stella Maris Hospital, making it a class B private hospital, according to data from the preceding three years. Patients and their families have expressed their dissatisfaction with the Stella Maris Hospital Makassar Outpatient Installation, claiming that treatment wait times are still much too long.

\section{Methods}

This research was carried out in the Outpatient Installation of Stella Maris Hospital Makassar in April 2022. The research interviewed eight informants, including the hospital's director, the head of the outpatient facility, admission officers, and nurses. The methodologies used in this study comprised a mix of interviewing and observation. Data reduction was used to sort, eliminate, simplify, abstract, and modify coarse data collected in the field, as well as to pick and organize data and remove redundant data. The study team spoke with eight participants, including the hospital's director, the director of the outpatient facility, admission officers, and nurses, as part of their investigation. Using a timer and interview guidelines, an observation sheet is used to record patient service wait times, with the data being collected using a data 
collection tool. A data reduction technique was used to sort and delete data from the field, as well as to simplify, abstract, and change coarse data. It was also used to choose and arrange data and remove unnecessary information. Data is presented in the form of brief explanations, charts, and connections between different categories.

\section{Results and Discussion}

Table 1 depicts the Stella Maris Hospital in Makassar's staff's distribution of informants. Starting with the process of assigning a queue number to a patient and finishing with the patient being reviewed by a physician, the researcher breaks each patient service operation into flowcharts. The queue number is taken at the counter by pressing the machine button. In addition, patients must pass across the corridor to get to the counter where their wait number is recorded, and the hospital's queue numbering system is notoriously unreliable.

Table 1. The distribution of informants among personnel

\begin{tabular}{|l|l|c|c|c|c|}
\hline No & Activity & $\begin{array}{c}\text { Type of } \\
\text { Activity }\end{array}$ & $\begin{array}{c}\text { Average } \\
\text { time } \\
\text { (minutes) }\end{array}$ & $\begin{array}{c}\text { Highest } \\
\text { time } \\
\text { (minutes) }\end{array}$ & $\begin{array}{c}\text { Lowest } \\
\text { time } \\
\text { (minutes) }\end{array}$ \\
\hline 1 & The patient comes & VAIN & 0,1 & 1 & 0 \\
\hline 2 & $\begin{array}{l}\text { Patients walk through a } \\
\text { distant corridor leading } \\
\text { to a queue number } \\
\text { retrieval machine }\end{array}$ & NGOES & 1 & 2 & 0,2 \\
\hline 3 & $\begin{array}{l}\text { Patients queue up to } \\
\text { pick up queue numbers }\end{array}$ & NVA & 0,2 & 1 & 0,5 \\
\hline 4 & $\begin{array}{l}\text { The patient takes the } \\
\text { queue number }\end{array}$ & VAIN & 0,6 & 2 & 0,3 \\
\hline 5 & $\begin{array}{l}\text { Patient to front of } \\
\text { registration counter to } \\
\text { wait for queue turn }\end{array}$ & NVA & 5 & 30 & 1 \\
\hline
\end{tabular}

"When a patient enters the hospital via the main door, he or she is directed to the officer/security officer stationed in the hospital lobby in front of the queuing machine counter to the poly." (I.1)

"The queue number retrieval mechanism here often malfunctions; at times, we admission officers get overwhelmed when the queue number malfunctions, since it disrupts our service" (I.2)

In order to register as a patient at the hospital, patients must first stand in line at the patient registration counter, where they are met by a member of staff who takes their information and records it into their medical record file at the hospital.

Table 2. The service at the patient registration counter

\begin{tabular}{|l|l|c|c|c|c|}
\hline No & Activity & $\begin{array}{c}\text { Type of } \\
\text { Activity }\end{array}$ & $\begin{array}{c}\text { Average } \\
\text { time } \\
\text { (minutes) }\end{array}$ & $\begin{array}{c}\text { Highest } \\
\text { time } \\
\text { (minutes) }\end{array}$ & $\begin{array}{c}\text { Lowest } \\
\text { time } \\
\text { (minutes) }\end{array}$ \\
\hline 1 & $\begin{array}{l}\text { The patient sits in a chair to wait for } \\
\text { his turn to be called according to his } \\
\text { queue number }\end{array}$ & VAIN & 18 & 60 & 1 \\
\hline 2 & $\begin{array}{l}\text { Patient hands queue paper to } \\
\text { admissions officer }\end{array}$ & VAIN & 0,1 & 10 & 1 \\
\hline
\end{tabular}

Copyright $@$ (2022, Journal of Asian Multicultural Research for Medical and Health Science Study, Under the license CC BY-SA 4.0 


\begin{tabular}{|c|c|c|c|c|c|}
\hline No & Activity & $\begin{array}{l}\text { Type of } \\
\text { Activity }\end{array}$ & $\begin{array}{l}\text { Average } \\
\text { time } \\
\text { (minutes) } \\
\end{array}$ & $\begin{array}{l}\text { Highest } \\
\text { time } \\
\text { (minutes) }\end{array}$ & $\begin{array}{c}\text { Lowest } \\
\text { time } \\
\text { (minutes) } \\
\end{array}$ \\
\hline 3 & $\begin{array}{l}\text { The patient provides a referral file to } \\
\text { the admissions officer }\end{array}$ & VAIN & 0,1 & 3 & 1 \\
\hline 4 & $\begin{array}{l}\text { Officers bypass ktp, kk, and kertu } \\
\text { patient guarantee to match data }\end{array}$ & VAIN & 0,1 & 3 & 1 \\
\hline 5 & The officer inputs patient data & VAIN & 2 & 7 & 1 \\
\hline 6 & Officers make SEP patients & VAIN & 2 & 8 & 1 \\
\hline 7 & $\begin{array}{l}\text { Officers await confirmation in the } \\
\text { central part of bpjs }\end{array}$ & NVA & 2 & 6 & 2 \\
\hline 8 & Officer prints patient SEP & VAIN & 2 & 3 & 1 \\
\hline 9 & $\begin{array}{l}\text { Admissions officer gives patient files } \\
\text { to medical records officer }\end{array}$ & NVA & 0,5 & 2 & 1 \\
\hline 10 & $\begin{array}{l}\text { Medical records officer records } \\
\text { patient's medical records file }\end{array}$ & VAIN & 1 & 5 & 1 \\
\hline 11 & $\begin{array}{l}\text { Medical records officer searches for } \\
\text { patient's medical records }\end{array}$ & NVA & 2 & 3 & 1 \\
\hline 12 & $\begin{array}{l}\text { Admissions officer confirms doctor's } \\
\text { schedule to poly nurse }\end{array}$ & NVA & 3 & 2 & 1 \\
\hline 13 & $\begin{array}{l}\text { The admissions officer informs the } \\
\text { passivity about the doctor on duty } \\
\text { coming at such an hour. }\end{array}$ & VAIN & 0,1 & 2 & 1 \\
\hline 14 & $\begin{array}{l}\text { Admissions officer gives queue paper } \\
\text { to patient to get to poly }\end{array}$ & VAIN & 1 & 2 & 1 \\
\hline 15 & $\begin{array}{l}\text { The patient is directed to go to the } \\
\text { poly }\end{array}$ & VAIN & 0,3 & 2 & 1 \\
\hline
\end{tabular}

As one informant said in the interview:

"What contributes to the length of time it takes for patients to be processed for registration at the BPJS center is the presence of network interruptions from the center, which prolong the procedure." (I.3)

"Typically, when I serve a patient, several other patients inquire, and I direct the patient" (I.4)

According to statistics on patient wait times for services, it is known that outpatient services begin when the patient is called to the registration counter with the patient number assigned by the queue number and the patient number assigned by the queue number. Whenever a patient is called to the registration counter and is a member of the BPJS, troubles often develop throughout the SEP process as a result of internet connection problems, printing failures, and patient medical record file storage mistakes (human error).

"When the network from the BPJS center goes down at 11.00 WITA, the patient registration counter's printer is only accessible 1; in addition, patients sometimes come to the registration counter to ask questions if they don't understand what they are being told. As a consequence, whenever I interact with patients, I am overcome with emotion" (I.5) 
3 Table First and foremost, the medical record file must be sent to the doctor's office while the patient is waiting to be called into the examination room. Typically, the doctor is tardy in his or her arrival, and the patient must wait for quite some time before being seen by the physician. Patient numbers or names will be called for scrutiny after the patient has completed the process of receiving a queue number and registering that number.

Table 3. The process of waiting for the patient

\begin{tabular}{|l|l|c|c|c|c|}
\hline No & Activity & $\begin{array}{c}\text { Type of } \\
\text { Activity }\end{array}$ & $\begin{array}{c}\text { Average } \\
\text { time } \\
\text { (minutes) }\end{array}$ & $\begin{array}{c}\text { Highest } \\
\text { time } \\
\text { (minutes) }\end{array}$ & $\begin{array}{c}\text { Lowest } \\
\text { time } \\
\text { (minutes) }\end{array}$ \\
\hline 1 & $\begin{array}{l}\text { Medical records officer } \\
\text { brings medical records } \\
\text { of patients to nurses }\end{array}$ & NVA & 4 & 18 & 2 \\
\hline 2 & $\begin{array}{l}\text { Nurse standing at } \\
\text { nurse's post checks } \\
\text { patient's medical } \\
\text { records file }\end{array}$ & VAIN & 1 & 3 & 0,5 \\
\hline 3 & $\begin{array}{l}\text { Nurses take rm patient } \\
\text { files into the doctor's } \\
\text { room }\end{array}$ & NVA & 0,7 & 0,3 & 1 \\
\hline 4 & $\begin{array}{l}\text { Patient hands nurse } \\
\text { post patient queue } \\
\text { paper }\end{array}$ & NGOES & 1 & 1 & 0,4 \\
\hline 5 & $\begin{array}{l}\text { Nurses take patient } \\
\text { queue paper and are } \\
\text { taken into the doctor's } \\
\text { room }\end{array}$ & NVA & 3 & 8 & 1 \\
\hline 6 & $\begin{array}{l}\text { The nurse standing at } \\
\text { the nurse's post directs } \\
\text { the patient to perform } \\
\text { initial examinations } \\
\text { such as measuring } \\
\text { weight, blood pressure } \\
\text { and asking the patient's } \\
\text { complaints. }\end{array}$ & VAIN & 1 & 0,3 & 0,1 \\
\hline 7 & $\begin{array}{l}\text { The patient waits for } \\
\text { the doctor to come and } \\
\text { is called in for an } \\
\text { examination. }\end{array}$ & NVA & 72 & 134 & 13 \\
\hline & & & & & \\
\hline & & & & & \\
\hline & & & & & \\
\hline & & & & & \\
\hline & & & & & \\
\hline & & & & & \\
\hline
\end{tabular}

As one informant said in the interview:

"Sometimes the medical record file carried by the medical record officer from the registration counter is generally sluggish to come, and the doctor always arrives late according to the timetable established by the hospital, but before that, I as a nurse first phoned the doctor to inquire what time he arrived." As a result of the physicians who have yet to come, the outpatient polyclinic's waiting room is packed." (I.6)

"The challenge was that the doctor was delayed to arrive, so the patient came to ask questions and inquire about it" (I.7) 
Systematic diagrams or techniques for mapping the flow of information into an allencompassing picture that incorporates every action in a system are known as "value stream mapping" (VSM). It is the purpose of lean manufacturing to remove waste from a system or process and enhance its effectiveness and efficiency. One of the instruments utilized to determine the mix of value contributed and non-value added activities was direct field observations to map the value stream of patient care activities.

It is shown in (figure 4.1) that employing VSM on the Outpatient Patient Service reduces the queue taking procedure's cycle time to 2.1 minutes on average, and the transfer procedure's time to 0.1 minutes on average, with a range of 6 minutes to 1 minute. Wait times in this region range from 5 minutes to 30 minutes, with the least wait time clocking in at 5 minutes.

It takes an average of 16 minutes to register a patient's queue number at the registration counter, with a 0.1-minute transfer to the following stage. An hour and a half is the greatest wait time, while just a minute is the shortest wait period.

In addition, the patient has a maximum examination duration of 30 minutes and a minimum examination time of 4 minutes within the 9 -minute examination cycle. This operation has a $72-$ minute wait time on average. The longest recording lasted for 134 minutes, while the shortest recording lasted for just 13 seconds.

It takes an average of 122.2 minutes to care for a patient, with 27.2 minutes ( 22.3 percent) dedicated to value-added activities, and 95 minutes devoted to non-value-added activities (NVA) (77.7 percent ).

The goal of this research is to investigate the waiting time for outpatient treatments at the Stella Maris Hospital in Makassar, Indonesia, using the lean approach. There are a number of steps in the service process that are covered in this research, starting with the allocation of patient queue numbers, moving on through patient registration, and ending with the patient's admittance into the exam room.

According to the lean concept, if an activity does not provide value to the client, it is considered waste and must be removed or minimized. Prior to implementing lean management, a problem must be identified. Each process is examined to see whether or not there are any non-valueadded activities (NVAs) or wastes in the activities or processes that take place. Lean methodologies such as Value Stream Mapping (VSM), Visual Management (VM), waste identification (WI), and root cause analysis (RCA) were used throughout the investigation. (2014) (Lawal and others)

Lean emphasizes the need of bringing problems to light. On the surface, issues will be apparent, and action will be taken promptly to address them. Material, processes, and resources are arranged in a continuous flow such that when a problem develops, the operation is paused and solutions are found (Agustianingsih, 2011).

When it comes to determining which patient care activities create value and which don't, Makassar's Stella Maris Hospital uses a process called value stream mapping.

This research, known as Value Stream Mapping (VSM), focuses on the whole process of medical care, starting with the gathering of patient queue numbers and continuing through to patient registration and the examination room. These two currents are inseparably connected in some way.

It is possible to discover the root cause of non-value added or waste by recognizing the problem itself. Researchers may more easily identify the underlying causes of problems by using fish bone diagrams, which provide a visual representation of the problem. Man, material, technique,

Copyright $@$ 2022, Journal of Asian Multicultural Research for Medical and Health Science Study, Under the license CC BY-SA 4.0 
environment, and machine have been identified as four (5) reasons of difficulty in the pharmaceutical supply management process.

Outpatient pharmacies might benefit from physical enhancements such as better visual management, better scheduling, better queue number retrieval machines, and SIMRS deployment, as well as outpatient facilities could benefit from creating patient flowcharts based on root cause analysis results. After the patient arrives and obtains a queue number, he or she is considered to have arrived at the doctor's examination room (60 minutes). Four more kinds of queue discipline have been defined by Sulistiyorini et al. (2012): FCFS (first-come, firstserved), often known as FIFO (out). (2) Last come, first served (LCFS) or last in, first out (LIFO) refers to the idea of being the last to arrive and the last to go at a location, such the ticket counter of a movie theater. As an example, the elevator's queuing system for the same floor; Customers with higher priorities receive service before those with lower priorities, even if the latter arrived earlier in the queue. (4) Priority service (PS) means that customers with higher priorities receive service before those with lower priorities, even if the latter arrived earlier in the queue. For example, a number of things might be to blame for an incidence like this. For example, a person who is ill is more severe than other patients at a doctor's office.

The patient care procedure at the Stella Maris Hospital in Makassar is based on the practice of taking the queue number till the patient arrives, according to researchers' observations. Doctors are coming in huge lines and patients are having issues with their registration counters; thus, they are kept waiting for quite some time as they wait for their examinations. Equipment for retrieving queue numbers and the internet network, both of which are often problematic.

\section{Conclusion}

Based on the results of the research, Value Stream Mapping is used to identify activities that generate value while also excluding activities that bring no value. According to VSM data on the patient service process in outpatient facilities, the average time required for the patient service process is 131 minutes, with details on value-added activities accounting for 27 minutes (21 percent) of that time and non-value-added activities accounting for the remaining 131 minutes of that time. It was possible to complete the task in 104 minutes (79 percent). Approximately $28 \%$ of value was supplied throughout the process of getting the patient queue number, whilst $72 \%$ of no value was added during the procedure. On average, 47 percent of patient registration procedures at the admissions counter are worth doing, whereas 53 percent of them aren't worth doing at all. The process of sitting in a doctor's waiting room contributes 10 percent to the value of the service and 90 percent to its non-value. There were four types of waste identified in non-value added activities at the Stella Maris Hospital in Makassar: the Queue Number Collection Counter (which had two types of waste, namely waiting and motion), the patient registration counter (which had three types of waste, namely waiting, motion, and overproduction), and the waiting room for a doctor's examination (4 types of waste, namely waiting, motion, over production and waste of human resources). After conducting a fishbone analysis, it was discovered that the root cause of patient service waiting time was caused by four factors: man (a doctor's delay), machine (a hospital management information system that was not operational, queuing machines that frequently failed, an internet network that frequently failed, a lack of a monitor screen and a lack of a number at the registration counter), and environment (distance from the patient entrance to the remote queue number collection counrty). The implementation of an integrated hospital management information system, the repair of the queue machine at the queue number taking counter, the improvement of the queue number taking counter's layout, the improvement of the doctor's schedule, and the 
procurement of spo during doctor's arrival hours are all part of the proposed improvement with lean tools.

\section{References}

Elisabeth Dyah Noviani (2017). Penerapan Lean Manajemen pada Pelayanan Rawat Jalan Pasien BPJS Rumah Sakit Hermina Depok Tahun 2017. Jurnal ARSI.

Graban, M. (2016). Lean hospitals: improving quality, patient safety, and employee engagement. CRC press.

Kinsman, L., Harrison, E. L., Plishka, C. T., Rotter, T., Adegboyega, L., Chan, J. G., ... Fiander, M. (2017). Lean management in health care: effects on patient outcomes, professional practice, and healthcare systems. Cochrane Database of Systematic Reviews, (11). https://doi.org/10.1002/14651858.cd012831

Kurnia Widyaningrum, dkk. (2015) X Factors Influencing The Optimization Of Outpatient Unit In X Hospital 28(2), 136-140.

Kurniasih, D., \& Pribadi, F. (2021). Implementasi Lean Hospital Dalam Meningkatkan Pelayanan Rawat Jalan Poliklinik Penyakit Dalam ( Studi Kasus d i Rumah Sakit “ X "Indonesia ). 28, 1-14.

Laeliyah, N., \& Subekti, H. (2016). Waktu Tunggu Pelayanan Rawat Jalan dengan Kepuasan Pasien Terhadap Pelayanan di Rawat Jalan RSUD Kabupaten Indramayu. 1(2), 110.

Lawal, A. K., Rotter, T., Kinsman, L., Sari, N., Harrison, L., Jeffery, C., ... Flynn, R. (2014). Lean management in health care: Definition, concepts, methodology and effects reported (systematic review protocol). Systematic Reviews, 3(1), 1-6. https://doi.org/10.1186/2046-4053-3-103

Torry, Koeswo, M., \& Sujianto. (2016). Faktor yang Mempengaruhi Waktu Tunggu Pelayanan Kesehatan kaitannya dengan Kepuasan Pasien Rawat Jalan Klinik penyakit dalam RSUD Dr. Iskak Tulungagung Factors Influencing Service Waiting Times in Relation to Internist Clinic Outpatient's satisfaction. 29(3), 252-257. 